\title{
Opportunities, Constraints and Perceptions of Rural Communities Regarding Their Potential to Contribute to Forest Landscape Transitions Under REDD+: Case Studies from Mexico
}

Author(s): M. Skutsch, A. Borrego, L. Morales-Barquero, J. Paneque-Gálvez, M. Salinas-Melgoza, M.I. Ramirez, D. Perez-Salicrup, D. Benet, S. Monroy and Y. Gao

Source: International Forestry Review, 17(S1):65-84.

Published By: Commonwealth Forestry Association

URL: http://www.bioone.org/doi/full/10.1505/146554815814669025

BioOne (www.bioone.org) is a nonprofit, online aggregation of core research in the biological, ecological, and environmental sciences. BioOne provides a sustainable online platform for over 170 journals and books published by nonprofit societies, associations, museums, institutions, and presses.

Your use of this PDF, the BioOne Web site, and all posted and associated content indicates your acceptance of BioOne's Terms of Use, available at www.bioone.org/page/terms_of_use.

Usage of BioOne content is strictly limited to personal, educational, and non-commercial use. Commercial inquiries or rights and permissions requests should be directed to the individual publisher as copyright holder. 


\title{
Opportunities, constraints and perceptions of rural com- munities regarding their potential to contribute to forest landscape transitions under REDD+: case studies from Mexico
}

\author{
M. SKUTSCH ${ }^{1}$, A. BORREGO ${ }^{2}$, L. MORALES-BARQUERO ${ }^{3}$, J. PANEQUE-GÁLVEZ ${ }^{4}$, M. SALINAS-MELGOZA ${ }^{5}$, \\ M.I. RAMIREZ ${ }^{6}$, D. PEREZ-SALICRUP ${ }^{7}$, D. BENET ${ }^{8}$, S. MONROY ${ }^{9}$ and Y. GAO $^{8}$
}

${ }^{1}$ Senior Researcher, Centro de Investigaciones en Geografía Ambiental (CIGA), Universidad Nacional Autónoma de México (UNAM), Antigua Carretera a Pátzcuaro No 8701, Col. Ex-Hacienda de San José de La Huerta, 58190 Morelia, Michoacan, Mexico ${ }^{2}$ Postdoctoral Research Fellow, Facultad de Economía, Universidad Nacional Autónoma de México (UNAM), 04510 Ciudad Universitaria, Mexico D.F., Mexico

${ }^{3}$ PhD Candidate, School of Environment, Natural Resources and Geography, Bangor University, Deiniol Road, Bangor Gwynedd, LL57 $2 U W$ Wales, and with Chair of Forest Inventory and Remote Sensing, Burckhardt-Institute, Georg-August-Universität Göttingen, Büsgenweg 5 , Göttingen, 37077, Germany

${ }^{4}$ Postdoctoral Research Fellow, Centro de Investigaciones en Geografía Ambiental (CIGA), Universidad Nacional Autónoma de México (UNAM), Antigua Carretera a Pátzcuaro No 8701, Col. Ex-Hacienda de San José de La Huerta, 58190 Morelia, Michoacan, Mexico ${ }^{5}$ PhD Candidate, Twente Centre for Studies in Technology and Sustainable Development, Twente University, 7522 NB Enschede,

The Netherlands

${ }^{6}$ Senior Researcher, Centro de Investigaciones en Geografía Ambiental (CIGA), Universidad Nacional Autónoma de México (UNAM), Antigua Carretera a Pátzcuaro No 8701, Col. Ex-Hacienda de San José de La Huerta, 58190 Morelia, Michoacan, Mexico

${ }^{7}$ Senior Researcher, Centro de Investigaciones en Ecosistemas (CIECO), Universidad Nacional Autónoma de México (UNAM), Antigua Carretera a Pátzcuaro No 8701, Col. Ex-Hacienda de San José de La Huerta, 58190 Morelia, Michoacan, Mexico

${ }^{8}$ Researcher, Centro de Investigaciones en Geografía Ambiental (CIGA), Universidad Nacional Autónoma de México (UNAM), Antigua Carretera a Pátzcuaro No 8701, Col. Ex-Hacienda de San José de La Huerta, 58190 Morelia, Michoacan, Mexico

${ }^{9}$ Masters student, Centro de Investigaciones en Ecosistemas (CIECO), Universidad Nacional Autónoma de México (UNAM), Antigua Carretera a Pátzcuaro No 8701, Col. Ex-Hacienda de San José de La Huerta, 58190 Morelia, Michoacan, Mexico

Email: mskutsch@ciga.unam.mx,armoniab@gmail.com,moralesluciacr@gmail.com,jpanequegalvez@gmail.com, ma.masm@gmail.com, isabelrr@ciga.unam.mx,diego@cieco.unam.mx,dbenet@pmip.unam.mx, sofiamonsais@gmail.com, ygao@ciga.unam.mx

\section{SUMMARY}

In Mexico, REDD+ is being presented as a win-win policy enabling forest communities to benefit financially and diversify their income sources while preserving and increasing their forest carbon stocks through more sustainable management. Under the national programme, it is expected that forest communities will have opportunities to tailor their own approaches. However, to date there is little understanding about what opportunities and constraints exist in reality for forest communities to contribute to REDD+, and even less about how their members perceive these opportunities. We assess potential and constraints at community level and investigate perceptions about opportunities in REDD+ and strategies that communities are currently envisaging for participation, in seven communities in the Ayuquila River Basin and around the Chamela-Cuixmala Biosphere Reserve in Jalisco, and in the area surrounding the Monarch Butterfly Reserve in Michoacan. We find that there is more opportunity for reduced degradation and forest enhancement than for reduced deforestation, in all the communities; that it may be difficult to establish additionality for REDD+ activities in some communities; that the amount of forest resource per community may greatly affect the potential to participate; that the presence of people with no land rights may complicate the distribution of benefits; that communities expect REDD+ in general to follow the Payment for Environmental Services model, and that lack of information about what activities may count as REDD+ activities and what level of financial rewards may be expected mean that communities cannot at present adequately appraise whether REDD+ will be worth their while or not.

Keywords: forest degradation, Payment for Ecosystem Services (PES), community forest management, benefit sharing 


\title{
Opportunités, contraintes et perceptions des communautés rurales et leur capacité à contribuer aux transitions des paysages forestiers dans le contexte de REDD+: études de cas au Mexique
}

\author{
M. SKUTSCH, A. BORREGO, L. MORALES, J. PANEQUE-GÁLVEZ, M. SALINAS-MELGOZA, M.I. RAMIREZ, \\ D. PEREZ-SALICRUP, D. BENET, S. MONROY et Y. GAO
}

Au Mexique, la REDD + est présentée comme une politique gagnant-gagnant permettant aux communautés forestières d'obtenir des bénéfices financiers et diversifier leurs sources de revenus tout en préservant et en augmentant leurs stocks de carbone forestiers, grâce à une gestion plus durable. Dans le cadre du programme national, il est prévu que les communautés forestières auront la possibilité d'adapter leurs propres approches. Cependant, il y a peu de compréhension de ce que sont réellement les possibilités et les contraintes pour les communautés forestières pour contribuer à la REDD+, et encore moins sur la façon dont leur membres perçoivent ces possibilités. Dans cette étude, nous évaluons le potentiel et les contraintes au niveau de la communauté et étudions les perceptions sur leurs opportunités au sein de REDD+ et les stratégies de participation qu'ils envisagent actuellement, dans sept communautés du bassin du fleuve Ayuquila, autour de la réserve de la biosphère de Chamela - Cuixmala au Jalisco, et dans la zone entourant la Réserve du Papillon Monarque dans le Michoacan. Nous constatons qu'il y a plus de possibilités pour éviter la dégradation de que réduire la déforestation, dans toutes les communautés; qu'il est difficile d'établir l'additionnalité des activités de REDD+ dans certaines communautés; que la quantité des ressources forestières peut grandement influer le potentiel de participer; que la présence de personnes sans droits fonciers peut compliquer la répartition des bénéfices; que les communautés attendent que REDD+ va suivre le modèle de paiement des services environnementaux; et que le manque d'informations relatives à quelles activités seront pris en comptes comme des activités REDD+ et quel niveau de récompenses financières peuvent être attendus signifie qu'à l'heure actuelle les communautés ne peuvent pas évaluer de manière adéquate s'il vaut la peine de s'impliquer en REDD+.

\section{Oportunidades, limitaciones y percepciones de comunidades rurales en relación con su poten- cial para contribuir a una transición en los paisajes forestales bajo REDD+: Casos de estudio en México}

\author{
M. SKUTSCH, A. BORREGO, L. MORALES, J. PANEQUE-GÁLVEZ, M. SALINAS-MELGOZA, M.I. RAMIREZ, \\ D. PEREZ-SALICRUP, D. BENET, S. MONROY y Y. GAO
}

En México, REDD+ está siendo presentada como una política ambiental positiva para todos, que permitirá a las comunidades forestales beneficiarse financieramente y diversificar sus fuentes de ingreso, a la vez que preservar e incrementar las reservas de carbono existentes en sus bosques, gracias a un manejo más sustentable de los mismos. A nivel nacional, se espera que las comunidades forestales tengan la oportunidad de adaptar esta política según sus necesidades. Sin embargo, todavía se sabe muy poco acerca de las oportunidades y limitaciones existentes para que las comunidades forestales puedan contribuir a la política REDD+, y aún se sabe menos sobre cómo los habitantes de comunidades forestales perciben estas oportunidades. En este artículo evaluamos el potencial y las limitaciones a escala de comunidad e investigamos las percepciones de las comunidades con relación a sus oportunidades en REDD+, así como qué estrategias están diseñando para participar en dicha política, en siete comunidades situadas en la cuenca del río Ayuquila y alrededor de la Reserva de la Biosfera Chamela-Cuixmala, en Jalisco, y en el área que rodea la Reserva de la Biosfera de la Mariposa Monarca, en Michoacán. Encontramos que en todas las comunidades estudiadas hay más oportunidades para evitar y revertir la degradación, que para reducir la deforestación; que puede ser difícil establecer la adicionalidad para actividades REDD+ en algunas comunidades; que la cantidad de recursos forestales existentes en la comunidad puede afectar enormemente el potencial para participar; que la presencia de habitantes sin derechos de propiedad de la tierra puede complicar la distribución de beneficios; que en general las comunidades esperan que REDD+ siga el modelo de Pagos por Servicios Ambientales; y que la falta de información sobre qué actividades pueden ser elegibles como actividades REDD+ y sobre qué nivel de beneficios económicos puede esperarse implica que las comunidades todavía no puedan evaluar de manera adecuada si su participación en REDD+ será beneficiosa o no.

\section{POLICY CONTEXT AND AIMS OF THE PAPER}

Although international policy on Reduced Emissions from Deforestation and forest Degradation (REDD+) could involve many different types of policy and programme interventions, it has been seen by many as one which could and should involve local communities in improved management and monitoring of forest (Chhatre and Agrawal 2009, Danielsen et al. 2011, Balooni and Lund 2013). Much of the critical literature on REDD+ policy focuses on how to ensure that rural communities that are traditionally dependent on forest resources, will benefit from REDD+ (Phelps et al. 2010, Di
Gregorio et al. 2013). The insertion of the idea of 'safeguards' into the policy framework was largely the result of fears of indigenous peoples and the organizations claiming to represent their interests, that REDD+ would result in their expulsion from forests, and that they would receive little or no financial benefit (Schroeder 2010, McDermott et al. 2012). Influential institutions such as the Centre for International Forestry Research (CIFOR) have also framed REDD+ primarily in terms of communities, reviewing for the purposes of a global comparative study (Angelsen et al. 2012) a range of projects in which local communities engage in forest management in return for some kind of reward - essentially using 
the Payment for Ecosystem Services (PES) model- with a view to understanding the potential impacts on livelihoods, but hardly dealing with other strategies (e.g., forest law enforcement or agricultural intensification).

This focus on community forest management as the heart of REDD+ is in some ways surprising, given that it has been recognized for a long time that most deforestation in the tropics is the result of conversion to large-scale commercial agriculture or cattle ranching (Angelsen and Kaimowitz 1999, Geist and Lambin 2001, Pacheco 2006, Gaveau et al. 2009, DeFries et al. 2010), and that unsustainable logging in the very carbon rich rainforests of the Amazon, the Congo Basin and SE Asia is also generally orchestrated by large companies, even if local people are co-opted as labourers (Geist and Lambin 2002). Nevertheless, there are many forest areas which even if officially owned by government or by companies, and threatened by such activities, are in practice utilized by the local population ('communities') to sustain their livelihoods. These forest areas provide, for example, sites for shifting cultivation (mainly for subsistence rather than sale), as well as for gathering firewood, fodder and numerous woody and non-woody products. For this reason, community forest management is seen as a viable REDD+ strategy in most of the planning documents submitted to the Forest Carbon Partnership Facility (FCPF) of the World Bank and the UN Collaborative Programme on REDD, both of which have been set up to provide financial support to early REDD+ efforts (Skutsch and McCall 2012). Moreover, it is the key or a central intervention envisaged in quite a number of cases (e.g., Tanzania, Nepal, Kenya, and Mexico).

The underlying assumption in these plans is that the incentive-based structure of REDD+ policy will encourage voluntary participation of communities, such that they will manage their forests in more sustainable ways than has been the case in the past, leading to a transition in forest landscapes from a situation in which they are losing tree-covered area and biomass density to one in which these processes are reversed. There has been relatively little consideration however about whether there are real opportunities here and whether there is in fact scope for such reversals and whether REDD+ policy can make it worthwhile for communities to strive for them. The physical scope for success relates to the characteristics of local forest resources, including the relative abundance of these, while willingness of the local population to participate will depend on current uses of the forest and perception of benefits and costs of the changes involved in REDD+.
Capacity to participate will depend in part on the level of social organization, at least where the forest resources are communal.

In this paper we make a preliminary analysis of seven communities in Mexico in which our central question is: what is their physical potential for a forest landscape transition towards higher carbon stocks under REDD+, taking into account past forest management practices, the potential for additionality ${ }^{1}$ and factors such as the ratio of people to forest area. We also attempt to assess the communities' social capacity for implementation and attitudes towards REDD+, particularly the level of community organization and the local sense of balance between costs and benefits of the policy.

Following this introduction, the paper starts by presenting in some detail the situation in Mexico, covering forest tenure, rates of deforestation and degradation, and the development of national REDD+ policy, including the uncertainties in how it will be implemented. We then introduce the three 'REDD+ Early Action Areas' over which the seven cases are distributed, briefly explain the methodology we employed, and present our findings and conclusions. Details of the individual cases are for reasons of space summarized in tables.

\section{COMMUNITY FORESTS AND REDD+ IN MEXICO}

A community based approach is particularly appropriate in Mexico, where a very large proportion of the forested area (estimates range from $80 \%$ to around 60\%: Bray et al. (2003), FAO (2010), Skutsch et al. (2013)) is legally in the hands of clearly defined communities, which are of two types, ejidos and comunidades ${ }^{2}$. Both were created as a result of policies of land redistribution after the Mexican Revolution (Assies 2008). Ejidos, which make up $90 \%$ of all rural communities, have a fixed number of members (ejidatarios), established at the time of the land assignation; comunidades have the right to grant membership to more members, if they so choose. Both types of communities have the right to decide how their common forest resources will be used, although officially they are not permitted to fully deforest without a government permit. Members of the community are entitled to shares in the benefits from management of the resources (e.g. timber if the forest is suitable for this, but also poles, firewood, non-timber forest products (NTFPs) such as resin and fungi, and the right to graze cattle). However, the real capacity to implement forest management plans may vary widely

\footnotetext{
1 Additionality refers to the fact that REDD+ payments are in principle only made for the improvements in carbon stocks that are over and above the 'business as usual' situation, as measured by a baseline which reflects recent trends in deforestation and degradation. This principle, which applies strictly at national level, may not necessarily be the basis for rewards at the local level, but nevertheless if REDD+ is to succeed it is clear that overall, the results of the REDD+ activities undertaken at local level will have to be additional, or there will be no credits to claim at national level.

2 'Ejidos' are agrarian nuclei formed by redistribution of land to landless people; their original members, who may have been drawn from many different parts of the country, are called 'ejidatarios'. They have common land (e.g. forests) and farmland parcels for each ejidatario. 'Comunidades' are agrarian nuclei of people whose native lands have been restituted to them; their members are called 'comuneros'. All their land is common property, although like ejidos, they frequently parcel out the farmland to individual comuneros (Cámera de Diputados 1992, Carrillo and Mota-Villanueva 2006). The internal institutions of these two forms of settlement are very similar, and in this paper we refer to both using the English term 'communities'.
} 
depending of the organization and capability for dealing with forest regulations and external conditions such as markets. Communities with good timber resources (particularly in pine and fir forests at higher altitudes, but also where there are hardwood species such a mahogany in the tropical lowlands) may rent these areas out to companies for exploitation, or they may set up their own internal timber companies/cooperatives. They may also allow individual members to extract and sell timber, and although there are some national restrictions on clearing the forest entirely, these are not always followed. However, a large part of Mexico's forested area, particularly the tropical dry forests (TDF), is not suitable for timber, and communities with these forest resources tend to use them for shifting cultivation, cattle grazing, and for extraction of firewood, charcoal, poles for fencing and stakes for tomato plants. This kind of forest is indeed hardly recognized as 'forest' (bosque in Spanish). It is commonly referred to by local people as 'monte', which has no direct translation into English but implies woodland with little commercial value. From an ecological point of view, however, TDF is very biodiverse and fulfils very important roles in the provision of environmental services (Maass et al. 2005, Balvanera 2012), and in its un-degraded state it has a canopy cover of well over $30 \%$, thus qualifying as forest under all UN Food and Agriculture Organisation (FAO) and UN Framework Convention on Climate Change (UNFCCC) definitions.

\section{Rates of deforestation and degradation in Mexico and their implications for REDD+}

Rates of deforestation and forest degradation are not known with any certainty in Mexico. While it is to be expected that such rates change over time, different sources suggest different rates of loss even for the same periods, probably as a result of different methodologies and definitions used (Trejo and Dirzo 2000, Velázquez et al. 2002, Couturier et al. 2012). The most recent official figures indicate a net annual forest loss of 354000 ha between 1993 and 2002, and of 155000 ha between 2002 and 2007, with the vast majority of losses $(>90 \%)$ in both periods occurring in tropical forests, while losses were very small in temperate forests ${ }^{3}$ (SEMARNAT, 2010). The apparent reduction in rates of forest loss after 2002 has never been convincingly explained. It may be associated with migration - particularly of males- from rural areas to cities within Mexico or to the US, with resulting abandonment of farming plots which then revert to forest. On the other hand, it could reflect macro-policy changes. For instance, the high levels of deforestation during the 1960s and 1970s were clearly related to general development policies that prevailed at that time, which encouraged clearing to promote agriculture and the commercial exploitation of timber (Jardel 1998). It was only in the 1990's that more conservationist policies were adopted. More recently, communities were encouraged to follow management plans for sustainable extraction of timber, with government subsidies to assist in this, and PES programmes were also introduced at community level for conservation of forest resources. Studies published on PES make it clear, however, that although PES has been to some extent effective in Mexico, much of the payment went to areas which would probably not have been deforested anyway (Alix-Garcia et al. 2005, Muñoz-Piña et al. 2008, Alix-Garcia et al. 2012), and no claims have been made by government that the reduced rates of deforestation in the last 10 years are the direct result of these programmes, although it has been shown that in areas of high deforestation pressure, PES programmes have had a small positive effect compared to other conservation policies (Honey-Rosés et al. 2011).

An important question relating to rates of deforestation and degradation is what the scope for further reduction in deforestation rates would be, since REDD+ is based on the principle of additionality. Deforestation rates would have to fall even faster in the future due to REDD+ related activities, in order for Mexico to claim REDD+ credits. Whether this could be achieved depends on the strength of the remaining drivers of deforestation and the opportunity and transaction costs involved. Communities that can earn large sums from selling their land for urban development, or from converting forests into high earning plantations such as avocado or agave, are unlikely to find REDD+ payments competitive.

In addition to avoiding deforestation, there are possibilities for financial rewards under REDD+ relating to avoided degradation, and to its inverse, the enhancement of forest stocks, which would be easier to measure in practice ${ }^{4}$ (Balderas Torres and Skutsch 2012). Degraded community forests could in principle be managed in such a way that their biomass/carbon stocks increase (forest enhancement), for which REDD+ credits can be claimed. In many ways this may be a more feasible strategy than trying to combat deforestation, as mentioned above, since it is likely to have lower opportunity costs and thus be more acceptable to communities.

\section{The development of community-based REDD+ policy in Mexico}

In 2008, the Mexican national forest commission CONAFOR launched a broad-based public discussion on REDD+, with financial assistance from a number of bi- and multi-lateral donors. A central aim of this was to draw in all the likely

\footnotetext{
3 Tropical forests include selvas bajas (tropical dry forests), selvas medianas and selvas altas (tropical humid forests). Temperate forests include both coniferous and broad leaf forests: pines, oaks, firs, etc.

${ }^{4}$ For the purposes of REDD+, 'forest degradation' refers to reduced density of woody biomass in forests which remain forests. The ' + ' in REDD+ includes forest enhancement (increases in forest area and/or density) and also sustainable management of forests and conservation. However, the latter two strategies refer more to the manner in which carbon savings could be achieved than to measurable changes in biomass/carbon stock which could be rewarded though performance payments.
} 
stakeholders, including communities, and to design a public policy on REDD+ that is workable and perceived to be legitimate by such stakeholders. The result has been the production of a (draft) National Strategy for REDD+ (ENAREDD+: Estrategia Nacional de REDD+: (SEMARNAT 2013)). This makes clear that Mexico sees REDD+ not just a policy aimed at forests and carbon, but as an opportunity to coordinate sectoral efforts to achieve the complementarity needed to support sustainable rural development, in a more holistic approach to livelihood development and environmental management (SEMARNAT 2013, p 5). Presumably any activities initiated under REDD+, whether based in the forest sector or in other sectors such as agriculture, would have to demonstrate some positive impact on carbon stocks, although it is not explicitly stated whether non-forest activities will be rewarded, and it is not clear how eventual rewards would be distributed. Meanwhile work has been done to build up the databases needed to develop baselines and to establish measuring, reporting and verification (MRV) systems that are sufficiently robust to satisfy international standards; and debate has taken place on who should be involved, and how the benefits should be distributed. Not surprisingly, these latter questions are subject to much more conflict, and they have not yet been fully resolved. Although there is certainly consensus that programmes should focus on communities, it is quite noticeable that very little attention has been given to what practical activities might be included under REDD+ at community level, and which activities would be likely to be most effective or cost-efficient in terms of carbon saving (Skutsch et al. 2013). This situation is not unique to Mexico but is a common weakness in national REDD+ planning documents.

It needs to be understood that what is under discussion here is a national approach to REDD+ in compliance with a UNFCCC system. Under a national system, carbon accounting would have in some way to be centralized, since for UNFCCC accreditation the allocation of carbon 'credits' depends on the net reductions in carbon emissions over the whole country. This is very different from experience with individual REDD-type projects, a handful of which have been operating in Mexico for some years. These work to their own rules and 'sell' their own credits overseas. Such projects assist communities to implement management programmes that reduce emissions, distributing the financial benefits to those involved as they see fit. In contrast, one of the real difficulties for a national level approach to REDD is that carbon gains in one part of the country may be cancelled out if there are heavy losses in another part. From the point of view of environmental integrity this is important and necessary to ensure that there is no 'leakage', at least within national borders. Understandably, however, there is considerable tension between those working at the local level, who wish to see benefits flow to any communities that successfully reduce emissions, and those who are responsible for the overall policy and national accounting.

All these difficulties have contributed to a situation in which, despite more than four years of public debate, there is not much clarity regarding what activities would be considered to be REDD+ activities, and how the government would encourage communities to engage in them. As mentioned above, CONAFOR already has many programmes supporting community forest management both as regards timber management (through programmes such as Procymaf (now discontinued), Silvicultura Comunitaria, Programa de Desarrollo Forestal Comunitario), and as regards conservation (through a series of PES programmes). It is still not clear whether REDD+ activities will be mostly of this sort or whether they may be much broader and cross sectoral, as implied in the preamble to the ENAREDD+. A recent draft document submitted to the FCPF (SEMARNAT 2014) suggests that 'implementing agents' at the sub-state level may take the lead in proposing packages of activities to communities in distinct geographical locations, which would then be approved by a broad-based state level committee. However, the list of activities suggested for the pilot areas (SEMARNAT 2014, pp 31-33) is heavily biased to forest based activities, and although it does include some formal land use planning activities at the community level (Ordenamiento Territorial Comuntario) it does not include any activities in sectors such as agriculture. What it does state however is that regular government financial sources may be used to support REDD+ activities, while the financial returns from the sale or exchange of carbon credits that result from these activities will be distributed to communities as investments to stimulate further forest management and conservation activities at local level in the second and subsequent years. It is not envisaged that these 'benefits' will be distributed according to performance in terms of carbon saved.

\section{Uncertainties regarding distribution of benefits}

Apart from the fact as mentioned above that it is not yet clear what kinds of activities would count as 'REDD+' activities, there are some uncertainties about who, within communities, might be eligible for REDD+ benefits. In most agrarian nuclei in Mexico, between one third and a half of the families are not officially members of the community, and while they may have been allocated some land for cultivation, they do not have formal rights to land nor to issues concerning land (e.g., voting in community meetings, a share in the benefits from land which is common property). Two distinct groups of people with limited rights may be present in Mexican communities. Posesionarios are people living in the community who have been allocated land but are not full members, cannot vote, and are not entitled to a share of the profits from communally held resources. They are often (adult) younger sons of ejidatarios, or former ejidatarios who have sold their rights. Avecindados are people/families living in the community who have no land, vote or entitlement. These may be people who are not land-dependent (teachers, shop keepers) or agricultural labourers, or people who live in the village but have farms outside the territory. Posesionairos and avecindados often have informal agreements with individual ejidatarios and work their land either for a wage or for a share of the crops. The number in each group is unsure: a 1996 study indicated that about one third of the households living within ejidos were without ejidal rights (Robles, 96). The 
number of posesionarios and avecindados has increased since then both as a result of population growth and of changes in law which have permitted limited individualization of parcels and sales of land and rights to community property since 1992. The 2010 census (INEGI 2010) shows that almost half of the population of agrarian settlements is without full rights. The significance of this for the current study is that although posesionarios and avecindados are frequently permitted by the village Assembly (i.e. by a quorum of the members) to use forests for subsistence purposes (fuelwood, fodder etc), in principle they have no rights to commercial benefits of the common forest. If REDD+ rewards were to be paid directly to communities, it is questionable whether posesionarios and avecindados would be eligible for a share.

Given the lack of certainty on what kinds of activities might be counted as 'REDD+ activities', on the magnitude and form in which benefits would be delivered, and on who might be eligible for benefit, NGOs and government agencies promoting REDD+ have been reluctant to go into such details, and the information they provide to communities is very general. It would therefore be very surprising if people living in communities in Mexico had clear ideas about whether they want to participate or not in REDD+. Aside from a few projects in the Voluntary Carbon sector such as Scolel Té (Smith and Scherr 2003), the situation at the moment is that the REDD+ activities that have been started in the framework of the national REDD+ programme in a few so called 'Early Action Areas' have focused mainly on the technical questions of how to measure and monitor carbon stocks and how to construct baselines. The government of Norway, for example, has sponsored national capacity building through CONAFOR, and the United States development agency USAID has sponsored a parallel project coordinated by The Nature Conservancy (TNC). In both of these, work has so far centered on creating the databases that will be needed for the national MRV system, and the few small projects which are actually taking place on the ground are mainly built on already existing initiatives.

\section{CASE STUDIES}

CONAFOR has nominated a number of states as 'REDD+ Early Action Areas' for implementation of pilot projects (Yucatan, Quintana Roo, Campeche, and Chiapas) as well as watershed areas in Jalisco. Criteria for the selection are broadly the pressure that forests are under, their environmental value, social needs (poverty) and the presence of sufficient local stakeholders (SEMARNAT, 2011), but why whole states are included is not entirely clear. The TNC project has identified its own much smaller 'Early Action Areas' which to some extent overlap with CONAFOR's. We selected three communities in the area of the Monarch Butterfly Biosphere Reserve (MBBR) in Michoacan, in one of the TNC Early Action
Areas, and three in the Ayuquila River Basin, close to the Sierra Manantlán Biosphere Reserve (SMBR) in Jalisco, in an early action area under both CONAFOR and TNC, where environmental planning is being carried out by the Junta Intermunicipal del Rio Ayuquila (JIRA), a local association of municipal governments. We also included one community that is within the western region of Jalisco, close to the Chamela-Cuixmala Biosphere Reserve (CCBR). This area is also within CONAFOR's Early Action area. It is receiving special attention for biodiversity conservation under the Cuencas Costeras programme, another PES-like programme provided by CONAFOR. The study areas are shown in Figure 1. The cases were selected because they were thought by project sponsors to be under threat of deforestation and thus to have potential for REDD+, but they have different histories as regards management and different levels of capacity in terms of internal social organisation. As mentioned earlier, the aim was to make a preliminary assessment of the physical potential for additionality in forest management under REDD+, and to consider also the social/organizational potential for such management. We also took note of local perceptions about REDD+ which could throw light on the communities' sense of whether it would be worth their while or not to participate.

\section{Description of case study area, Monarch Butterfly Biosphere Reserve}

The MBBR is one of the most emblematic protected areas in Mexico, where each year millions of monarch butterflies (Danaus plexippus L.) migrating from eastern Canada and the United States overwinter from November to March. This reserve is part of the UNESCO's Man and Biosphere Program and is a World Natural Heritage Site ${ }^{5}$. It is part of the eastern sub-basin of the Cutzamala System, which feeds water to large cities such as Toluca and Mexico City. Dominant natural vegetation changes from oak-pine to pine, pine-fir and fir forests as elevation increases (de Azcárate et al. 2003). During the last two decades, the study area has experienced high disturbance and deforestation rates mostly caused by illegal logging and, to a lesser extent, by authorized timber harvest, forest fires, domestic timber extraction, agricultural clearing, and natural forest loss (Honey-Rosés 2009, Navarrete et al. 2011).

In 2002, non-governmental organizations (NGOs) and Mexican federal and state environmental authorities created the Monarch Butterfly Conservation Fund (Fondo Monarca) to compensate forest owners within the MBBR core zone for their renunciation of existing logging licenses and to support conservation activities within this core zone (Missrie and Nelson 2005). A decade later, these payments, in combination with the law enforcement applied within of the protected area, have shown a positive effect in reducing forest degradation and deforestation and as well as recovering forest cover

5 UNESCO. 2014. Monarch Butterfly Biosphere Reserve.United Nations Education, Scientific and Cultural Organization. http://whc.unesco. org/en/list/1290 (Consulted: Feb 14, 14). 
FIGURE 1 The study sites are located in the margins of Biosphere Reserves indicated on the map

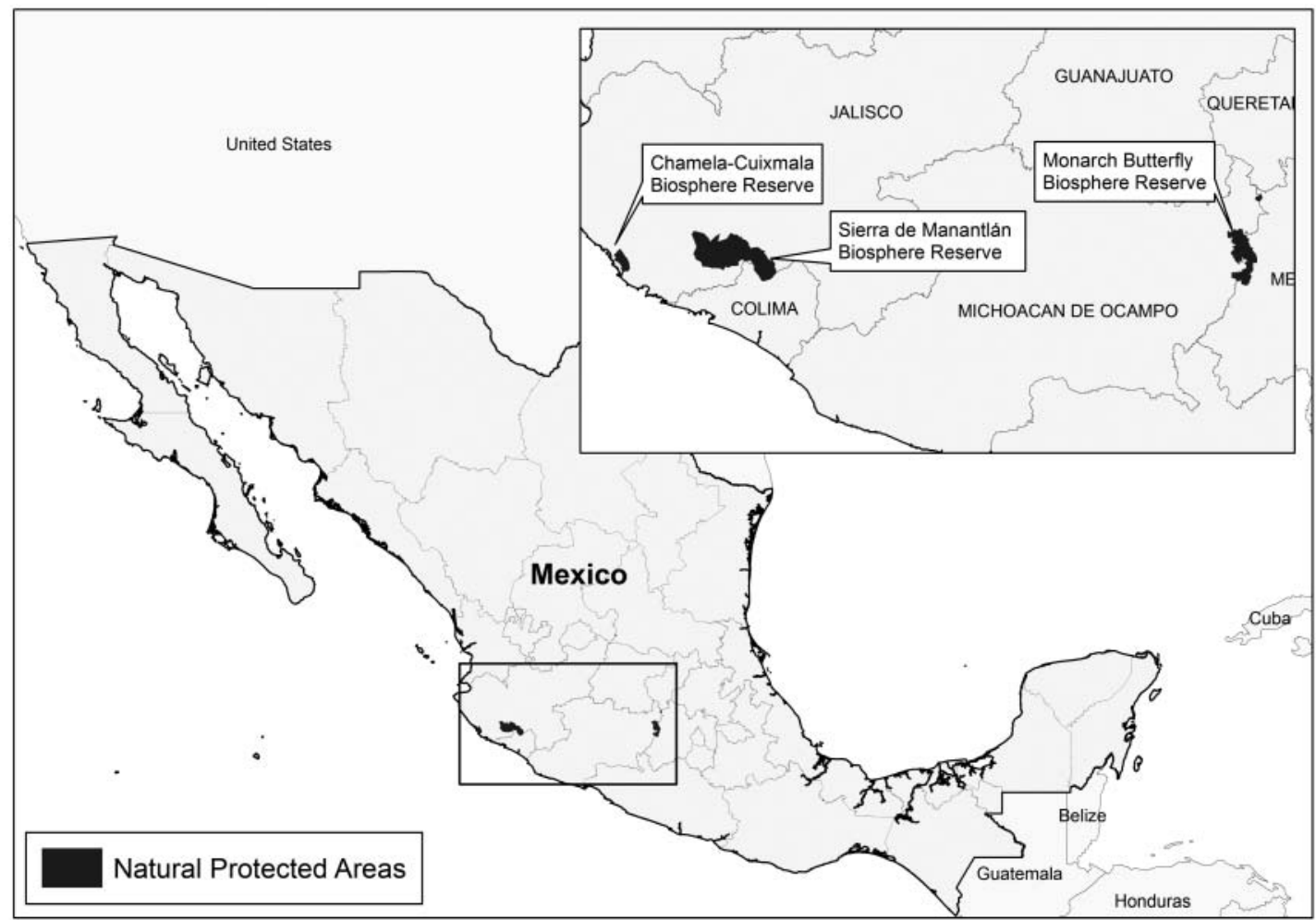

(Honey-Rosés et al. 2011, Vidal et al. 2014). Nevertheless, forest loss is still taking place within the reserve's buffer zone and the surrounding areas (Ramírez et al. 2014).

The TNC Early Action REDD+ project in this region involves five rural communities with varying degrees of social organization. In this report we present preliminary results based on the analysis of participatory workshops carried out with three of them (our cases A, B and C). Two of these (Cases A and C) have territory both in the core and buffer area of the Reserve, and both participate in the Fondo Monarca.

\section{Description of case study area, Ayuquila River Basin}

The area managed by JIRA covers part of the basin of the River Ayuquila in western Jalisco, and consists of a broad central area of undulating hills at an altitude of 700-1000 m, where large areas of the natural vegetation of TDF and scrubland have been cleared for permanent agriculture during the last 20 years. On the lower slopes to the south and east, TDF is much in use for shifting cultivation of maize, and for grazing, which has resulted in considerable degradation of the forest resources and possibly lowering of carbon stocks. At higher altitudes along the surrounding mountain chains (1000-2600 m) the vegetation changes to oak, oak-pine and finally pine forests, with isolated patches of cloud forest in high valleys. The SMBR was established in 1987 in the southern part of this area to protect the extraordinary biodiversity of the volcanic chain here. This reserve is also part of the UNESCO Man and Biosphere programme ${ }^{6}$. The establishment of the Reserve, whose area overlaps with more than 30 territories belonging to communities, has restricted the uses that local people can make of their forests, particularly when these fall within the core areas of the Reserve, but on the other hand, the staff of the Reserve has been influential in helping these same communities develop more sustainable management systems for the their natural resources and also to obtain funding for PES programmes.

The three communities (cases D, E and F) that are included in this study demonstrate different conditions both social and biophysical. All three are ejidos, and all have relatively small numbers of members. In all these settlements, the official members are heavily outnumbered by avecindados or posesionarios, which puts strain on community resources and decision making. In these communities, cattle rearing is a major economic activity and the common forest is informally parcelised between members, sometimes rented out to cattle owners from outside the community. Only one of the communities in this group (Case E) has significant areas of temperate forest with timber value. The forest area of the other two is made up largely of TDF. Both Case D and Case E have part of their territory within the core zone of SMBR, which implies that this part can be used only for conservation activities.

${ }^{6}$ UNESCO. 2014. Sierra de Manantlán Biosphere Reserve. United Nations Education, Scientific and Cultural Organization http://www. unesco.org $/ \mathrm{mabdb} / \mathrm{br} / \mathrm{brdir} /$ directory $/$ biores.asp? mode=gen \&code=MEX+06/. 


\section{Description of case study area, Chamela-Cuixmala}

The Cuencas Costeras environmental programme covers a large number of watersheds in the western part of Jalisco; the case study from this area (Case G) is located close to the CCBR, which in common with other biosphere reserves is part of the UNESCO programme. The vegetation in the area of study is primarily oak and TDF, with some cloud forest at higher elevations, and the primary means of livelihood in the area is cattle rearing. Case $\mathrm{G}$ is an ejido with approximately equal numbers of members and avecindados or posesionarios, and has a relatively large area of forest (pine, oak and cloud forest) per family, of which much, particularly the cloud forest, is highly inaccessible, and is currently under a PES programme.

\section{METHODOLOGY}

The study represents a preliminary diagnosis, based on rapid appraisal rather than in-depth studies, and was carried out because of the need to advise different REDD+ projects and sponsors on the potential for REDD+ in the communities concerned. While more in depth analysis would help to develop clearer advice for each village individually, the aim was to provide a comparative overview, indicating the range of possibilities and focusing on the differences between communities. Slightly different methods were used in the different zones, owing to differences in the requirements of the project sponsors, but observations and discussions focused around the following themes: the current state of the forest and reasons for this; the uses made of the forest; and forest management and conservation activities undertaken. These three themes, taken together with statistical data on population size etc. enabled us to make some broad assessments of the physical potential for REDD+. In additional we tried to appraise social capital and capacity for organization and forest governance, as well as attitudes towards REDD+.

Data on the three villages around the MBBR was gathered during one day community workshops which were carried out on behalf of the Alianza Mexico REDD+ in November 2013. The purpose of the workshops was to make a diagnosis of REDD+ potential using participatory mapping as a platform to elicit explanations for past forest events and for generating discussion on reasons for success and failure of past forest management initiatives. The maps used enlarged Google Earth images, onto which the official boundaries (according to the National Agrarian Register - RAN) had been overlaid (Figure 2 provides an example), and were primarily of value in generating discussion among participants, e.g. on areas which had been degraded and why. In each case, several working groups were formed around tables with copies of the maps, such that spatial identification of e.g. degraded or deforested areas, disputed zones, etc., could be triangulated. Participation at the workshops was open and ranged from 30 to 50 people, but it was evident that most of the participants were community members who had special interest in forestry issues and who had for example served on the forest watch brigades (vigilancia); most were ejidatarios or full community members, only a few posesionarios were present. This bias is unlikely to have affected estimates e.g. of degraded areas although it may possibly have affected interpretations of reasons for degradation. For the case of the villages in the Ayuquila Basin, the villages were those in which members of the research team had been working for some time, for the purposes of gathering data on carbon stocks and potential growth rates. Five focus group sessions were organized in 2012 and 2013 in these three villages, in which groups of 6-8 farmers were asked about their perceptions, opinions and attitudes towards a number of conservation programmes. In addition, during 2012 participatory mapping exercises similar to those used in the MBBR area were carried out to understand land use history as it might have affected carbon stocks. All these studies necessitated permission from the community assembly, i.e. the regular community meeting which is held to deliberate on community issues. Our team members then carried out 3-5 rounds of semi-structured interviews in each of the communities with village leaders and a wide range of individual members, including those without full rights. In addition, data was drawn from a series of household interviews to determine the likely effect on livelihoods of termination of activities which result in carbon emissions, particularly shifting cultivation. Finally, the community in Chamela-Cuixmala area was the subject of a detailed two year study (2011-2013) on environmental management involving extensive discussions with community leaders and members. Data on this case has largely been extracted from Monroy Sais, 2013.

Statistical data on population size and number of rights holders was drawn from secondary sources (INEGI Census 2010, RAN). Neither source can be taken to be very accurate; data on rights holders is particularly difficult to verify, mainly because the real situation on the ground is very complicated, as noted in the study made for the office of agrarian law (Procuraduría Agraria) (Robles, 1996). Although there are official statistics for some ejidos and comunidades in the RAN, these often differ enormously from local information (one minor reason being that the deceased are rarely removed from the RAN statistics). Moreover neither the official figures nor the local information on numbers in different groups adds up to the total adult population in the census, because women tend to be ignored unless they have land rights of their own, although the numbers of female ejidatarios has been growing (Robles, 1996). The total number of ejidatarios is likely to be reasonably accurate, since this is an externally and legally fixed quantity for each ejido, which can only be increased through a bureaucratic process to obtain permission of the Mexican government, unlike the number of comuneros in a comunidad, which can be increased by internal decision which means that male children of comuneros usually become comuneros themselves when they reach the age of 18 , while this is not the case for ejidatarios in ejidos. On the other hand, not all the ejidatarios are necessarily living in the ejido-some may have migrated for work leaving their families behind, while others may have moved with their families e.g. to reside in nearby towns, but still operate their farms in the ejido. 
FIGURE 2 Example of the results of the participatory mapping exercises

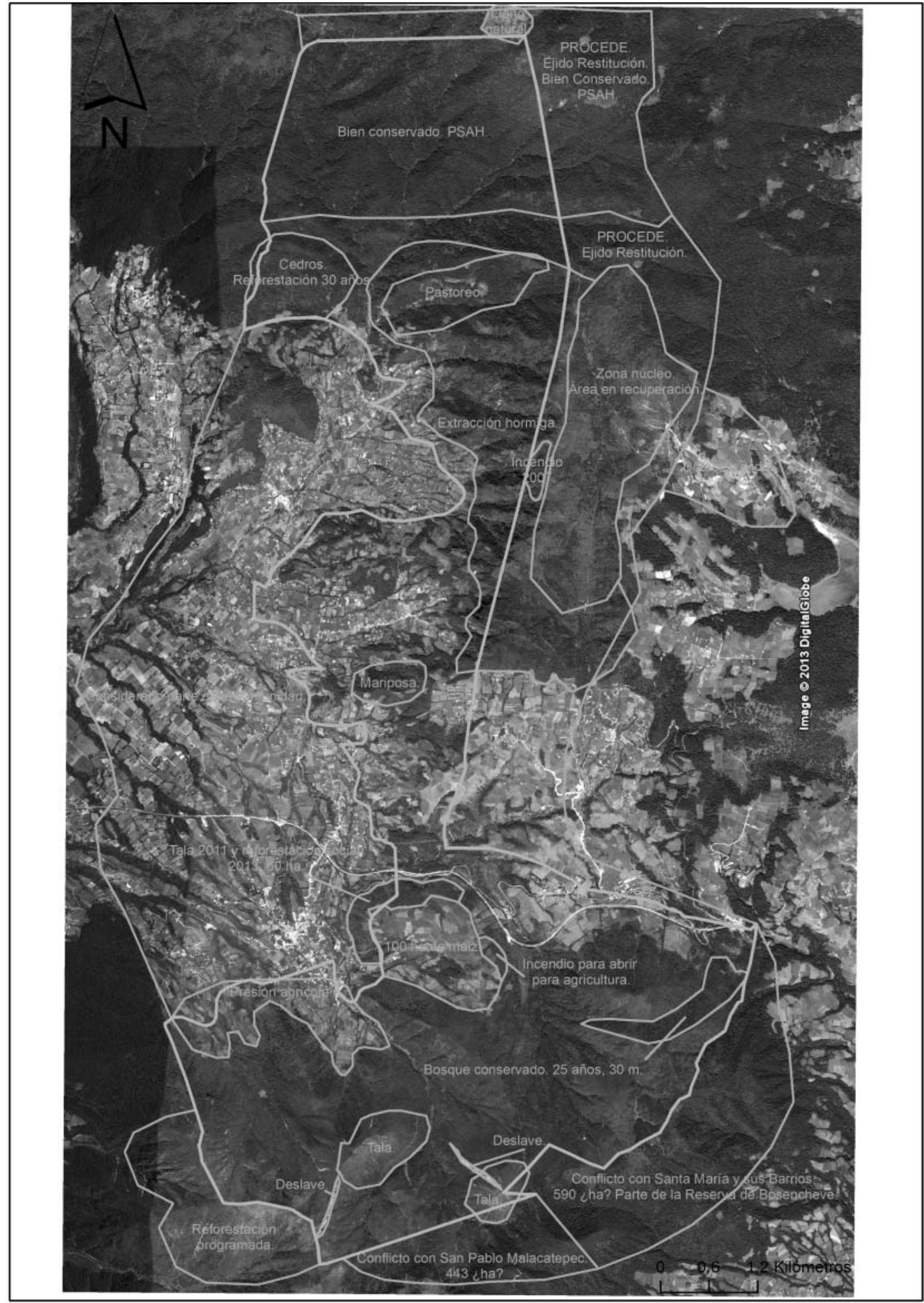

When it comes to avecindados the official figures usually grossly under-report as getting registered in the RAN entails a long legal process. In the local information, if the wife of an ejidatario is not herself an ejidatario, she may possibly be considered an avecindado but more usually she will not appear in any of these groups. Some of the avecindados are not land dependent and some may have private land outside the ejido/comunidad. Moreover the terms 'posesionario' and 'avecindado' are somewhat ambiguous in the minds of many people. In our estimates we have therefore combined these two groups, remaining with only two categories: rights holders vs. non-holders, and we have relied more on local information on numbers than on the official figures in the RAN in dividing the total number of households, relying on 
number of houses, rather than total adult population, as the marker. The figures presented in Table 1 are the best approximations we could make as regards demographic data. Table 2 shows the absolute and relative size of the resource base, and summaries of the situation as regards forest management in the villages are provided in Tables 3 to 5 .

\section{FINDINGS}

\section{The physical potential for participation and additionality}

Our observations and discussions with the communities indicate that there are only limited opportunities for REDD+ activities that would result in additionality in terms of carbon. Firstly, it is clear that the potential for REDD+ in these communities does not lie mainly in avoiding or reducing deforestation, which has been occurring only in a few of them, and only on a very small scale in these (e.g. in Case B, for small extensions of agricultural plots and Case E for small clearings in the forest for permanent pasture). The main area of opportunity seems to lie in tackling degradation and enhancing forest stocks through better management. However, several of the communities have already for some time been implementing environmental management strategies that reduce degradation and enhance forests, either on their own account (Cases B and E) or through government programmes such as PES (Cases B, D, F, G). It is questionable therefore whether these efforts could be credited under REDD+, as they are not 'additional' ${ }^{7}$. So for example the recovery of forest after fire damage in Case $\mathrm{C}$ is already well under way through natural regeneration. In case $\mathrm{F}$ a large part of the forest is recovering from its degraded state after it was placed under the SMBR.

There might however be additionality in opportunities for turning back the ongoing degradation of forests in Case A (through increased forest guards to prevent incursions of cattle and charcoal making from surrounding communities), Case $\mathrm{C}$ by reducing illegal extraction of timber, Case $\mathrm{E}$ by regulating cattle access to the forest to enable regeneration, and Case $\mathrm{G}$ by modification of the timber extraction plan. Fire watching and fire fighting could also be involved in all of these cases.

Although PES programmes appear on the surface to have been successful in many of these communities across all the zones (Cases B, D, F, G), in that the forest areas covered by the programmes have not been deforested or further degraded, it is evident too that the forest areas that were registered under the PES programme were selected by community authorities in areas with the lowest opportunity costs, i.e. in the areas which are the most inaccessible and therefore the least likely to be degraded or deforested (Cases C, G) or where there were in any case regulations which prevented degradation (Case F). In other words it is doubtful whether the conservation of these areas was actually the result of the payments made. This is particularly true for the four cases in Jalisco. If these programmes did not generally result in additionality, one may question whether similar approaches under REDD+ would. A second issue that may affect the physical potential of communities to participate effectively in REDD+ is the size of the resource base, and more particularly the relative size of this compared to the population. Table 2 indicates the ratio of forest to population, which is very different in the different regions studied, being very much lower in the MBBR communities than in Jalisco - around one tenth indicating the extreme pressure which these forests are facing and underlining the difficulty of placing what little there is per family under protection, since even if all timber extraction were halted, these forests would still need to be used for fuelwood and fence poles and as a source of cattle fodder, if not for grazing. The potential for activities which improve carbon stocks would be expected to be greater where there is more forest per head.

\section{Social capital, capacity for social organization and forest governance}

The villages vary greatly in the strength of their leadership in forest matters. Case $\mathrm{C}$ is a clear example of a community with a history of internal conflicts which spill over into resource management, making the achievement of a community consensus virtually impossible, with the result that the community-held forests are suffering a classic tragedy of the commons. Case D also illustrates major conflicts, due to the high proportion of inhabitants who do not have land, and the pressure to rent forest for grazing both to internal and external cattle owners. In a number of communities (specifically Cases A, C, D and G) forest management is directed by a small group within the community, members of which have taken it upon themselves to engage particularly in forest guarding activities (which often provides a small source of income). It might be thought that this concentration of decision making and financial resources in the hands of a small group would lead to greater conflict and to greater anarchy in forest resource use by those excluded from the group, but this does not in fact appear to be the case. However it is a practice that might well be carried over into REDD+, and its implications for equity in benefit sharing are important.

In the case of the communities in the MBBR area, there are on-going inter-community disputes over boundaries that have intensified as the Reserve has essentially enforced control over parts of the forest, using PES from the Fondo Monarca to sweeten the pill. In these communities the area of

\footnotetext{
7 Note that in discussing additionality, we are not assuming that distribution of benefits to communities would necessarily be tied to additionality of outcomes, indeed Mexico's recent REDD+ documents (e.g. SEMARNAT 2014) make it clear that benefits will not be distributed to communities in this way. Nevertheless if REDD+ activities at the community level do not create additionality in terms of carbon, they will not contribute to the national achievements and will not be able to earn credits internationally.
} 


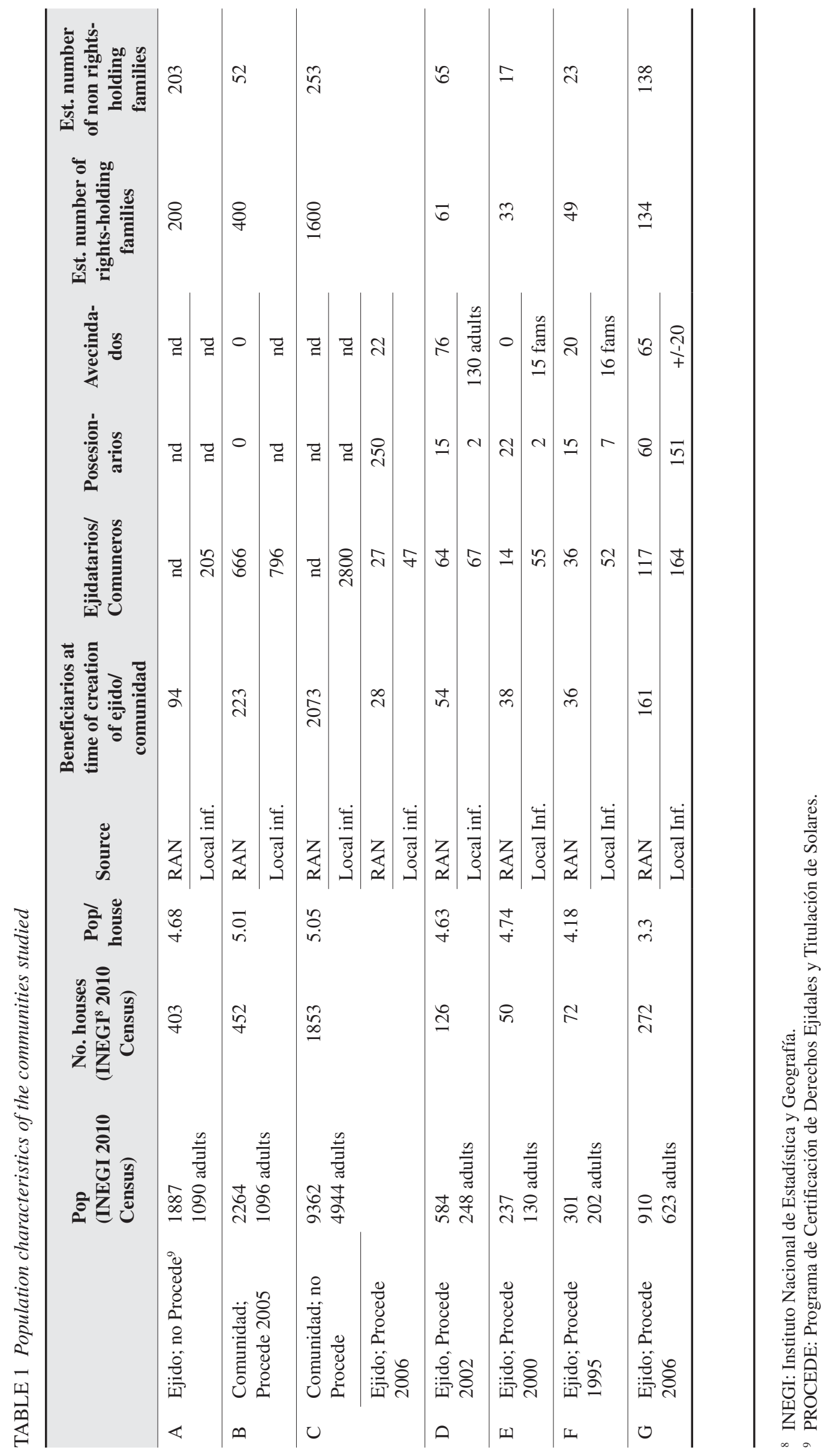


TABLE 2 Area of forest per head of population and per rights-owing family

\begin{tabular}{lccccc}
\hline & Total area (ha) & Area forest & Forest/inhabitant & $\begin{array}{c}\text { Forest/rights holding } \\
\text { family }\end{array}$ & $\begin{array}{c}\text { Approx \% of families } \\
\text { without rights }\end{array}$ \\
\hline $\mathrm{A}$ & 1412 & 752 & 0.39 & 3.76 & $50 \%$ \\
\hline $\mathrm{B}$ & 2579 & 1692 & 0.75 & 4.2 & $11 \%$ \\
\hline $\mathrm{C}$ & 7061 & $+/-3000$ & 0.32 & 1.9 & \\
\cline { 2 - 5 } $\mathrm{D}$ & 1719 & & & & $51 \%$ \\
\hline $\mathrm{E}$ & 4027 & 1741 & 3.0 & 28.5 & $34 \%$ \\
\hline $\mathrm{F}$ & 1476 & 922 & 4.2 & 30.1 & $31 \%$ \\
\hline $\mathrm{G}$ & 1599 & 1269 & 4.2 & 25.9 & $51 \%$ \\
\hline
\end{tabular}

forest per family is very small, which as we have noted above results in much higher levels of competition for forest resources both within and between communities.

The capacity to manage forests under REDD+ will also depend on the costs of the activities that will be undertaken and the sizes of the rewards that will be provided. At this point in time neither quantity is known, but it appears that in some villages (e.g. Case A) the costs of the current forest patrols cannot be covered by the profits from timber management, but is being subsidized from agriculture, a point which has not yet been discussed in academic studies on community forest management.

\section{Attitudes towards forest management, conservation and REDD+}

The communities made clear links between forest management and supply of environmental services, particularly those associated with direct use values such as water and 'fresh air/oxygen'. In general they have are favourable attitudes to conservation. It is clear, however, that most communities have little or no understanding of how REDD+ will work. In general they find carbon sequestration an easier concept to follow than reductions in emissions. Some have had earlier experience, e.g. of companies offering to 'buy their carbon' in return for long term total conservation deals (Case B), which make them distrustful of carbon projects. The role of forest technicians is very important here; their own personal interests and understanding of what REDD+ implies, and what programmes are likely to be associated with it, clearly vary greatly.

Many people in the villages understand the concept of PES, although not all members of the communities which already have PES programmes are fully aware of how they work. In most, there is awareness that part of the forest has been placed under a conservation programme which restricts its use, but awareness of the financial side of the deal varies between communities. In practice, communities are free to use the subsidy as they think best. In some it is divided between the members, but more commonly it is used by the community authorities to support forest management activities - particularly forest patrols - and in these villages the ordinary members are usually unaware of the quantities of money involved (which in reality are small). Many assume that REDD+ will involve a similar subsidy, raising the question of how this will be used or distributed internally. In general, although community members made the link between forest management and environmental services which are of value to themselves (particularly water and 'pure air'), they did not seem to envisage REDD+ as a vehicle for the promotion of wider sustainable rural development, as proposed by CONAFOR, but rather as another CONAFOR subsidy for forest work. In terms of opportunity costs and trade-offs anticipated, two of the Ayuquila villages (D and E) specifically mentioned the loss of rights to graze cattle in the forest, and this would certainly be an issue also in Case G where the forest is partially parcelised for this purpose, although forest grazing is already banned in the villages in MBBR. Potential loss of rights to use forest for shifting cultivation was not mentioned in any of the cases. In the MBBR it is no longer practiced in forest areas, and we believe that in cases $\mathrm{D}$ and $\mathrm{E}$ the villagers do not consider the areas they use for shifting cultivation as 'forest', but merely 'monte' (TDF) and thus have not taken on board the reality that uses of this type of forest might also be controlled under REDD+: in Case F the community has already taken steps to ban shifting cultivation. However, the impact of shifting cultivation on carbon stocks in TDF is under debate, with recent studies indicating that its effect may be rather small in the long run owing to the conservation of carbon in the soil (Salinas-Melgoza et al. 2014).

In Cases A, B and C forest patrols have been operating for some years, and at least in $\mathrm{B}$ and $\mathrm{C}$ the community sees this as the main activity to be expanded under REDD+ (to reduce forest fires and repel invasion for timber theft and cattle grazing by outsiders). Their preoccupation was therefore implementation costs, and whether REDD+ payments would be sufficient to pay for significant increases in patrols; in case $\mathrm{C}$ they also mentioned the need for finance for firearms for such patrols (although donors are unlikely to consider this a valid expenditure of REDD+ funds!) 
TABLE 3 Characteristics of case study communities in the Monarch Butterfly Biosphere Reserve

\begin{tabular}{ll}
\hline Cate of the A (ejido) \\
forest & Two distinct forest types: (1) Pine, \\
& with sustainable management plan \\
& for timber extraction, in good \\
& condition; small areas reforested and \\
& extensive natural regeneration over \\
& last 40 years. (2) Pine/ oak, not used \\
& for production for more than 30 \\
& years, badly degraded in parts, \\
& possibly by people from neighbour- \\
& ing ejidos illegally entering and \\
& felling trees, particularly for char- \\
& coal. Low biomass levels also relate \\
& to earlier ( $>40$ year ago) unsustain- \\
& able extraction activities and to a 2 \\
& major fires (10-15 years ago). Large \\
& parts of the forest are within the \\
buffer zone of the Monarch Butterfly & Reserve. \\
& Underlying issues: (1) Neighbouring \\
& communities that have exhausted \\
their own forest resources enter here & to fell trees illegally; (2) There is a \\
boundary dispute.
\end{tabular}

Uses of the (1) No shifting cultivation or grazing forest allowed in any forest areas; (2) Firewood for domestic use only; (3) Cattle from neighbouring settlements enter the pine/oak forest contributing to degradation; (4) Illegal charcoal making in pine/oak forest; (5) Timber extraction in pine forest is managed communally following a 10 year rotation plan.

Case B (comunidad)

Forest (largely pine, also pine-oak and fir) is in relatively good condition. Earlier ( $>40$ years ago) was used for timber extraction but not since then. Small parts not regenerating well; one area badly affected by fire 2001. Unauthorised encroachments at the margins of the cultivated areas (mainly for avocado plantations) but these are gradually being reversed by a community agreement reforest a part of these areas every year (no compensation paid). The seedlings for replanting are raised in a community nursery supported by an international NGO. Clearing more forest for agriculture was stopped 7 years ago by community decision in the assembly, and this decision appears to have been effective. Most of the forest is within the buffer and core zones of the Monarch Butterfly Reserve.

(1) No shifting cultivation or grazing allowed in any forest areas; (2) Firewood for domestic use; (3) No charcoal production; (4) With permission from the comisario, a family may be allowed to cut one tree for timber domestic purposes. in which the offenders have to

Case C (comunidad and ejido)

Forest (mostly pine, also pine-oak and fir) significantly degraded in many parts, particularly in the areas outside the Reserve. This is largely the result of illegal and uncontrolled timber extraction. In 1976 there was a major fire but part of this area was reforested and part has had natural regeneration. Fondo Monarcha supports conservation through a PES scheme in the part that abuts and overlaps with the buffer zone of the Reserve.

Relevant underlying issues: in 2005, a small number of members of the comunidad formed an ejido and took over part of the territory for themselves. This move is still disputed by many of the comuneros, who therefore do not feel bound by rules on timber extraction in that area. Most of the forest is within the buffer and core zones of the Monarch Butterfly Reserve.

(1) No shifting cultivation or grazing; (2) Illegal felling has been going on here for 40 years (both small scale internally driven and large scale externally driven, involving commercial concerns, with armed personnel and lorries). Worst period 2003-8 (30 illegal sawmills were operating in that period, now 2-3).

Relevant underlying issues: (1) Many external forces involved in the timber extraction, co-opting some groups within the community; (2) Reduced extraction since 2008 due to pressure from the Reserve and from the government (PROFEPA).

\begin{tabular}{|c|c|c|}
\hline $\begin{array}{l}\text { Forest } \\
\text { manage- } \\
\text { ment and } \\
\text { conserva- } \\
\text { tion } \\
\text { activities } \\
\text { undertaken }\end{array}$ & $\begin{array}{l}\text { (1) Planned timber harvesting; (2) } \\
\text { Forest patrols in the productive pine } \\
\text { forest, to lesser extent in the pine/oak } \\
\text { forest. The brigades are not paid } \\
\text { wages but get money for 'expenses'; } \\
\text { (3) Some small reforestation efforts. }\end{array}$ & $\begin{array}{l}\text { (1) Forest patrols ( } 24 \text { hours) mainly } \\
\text { on the borders of the forest where the } \\
\text { neighbouring villages may invade. } \\
\text { All male members of the community } \\
\text { have to take their turn in this; (2) } \\
\text { Reforestation is undertaken in small } \\
\text { areas annually (about } 10,000 \\
\text { seedlings per year). (3) The forest } \\
\text { within the Reserve's core zone is } \\
\text { under a PES scheme. }\end{array}$ \\
\hline
\end{tabular}

(1) Some small areas of reforestation (2) The forest within the Reserve's core zone is under a PES scheme. 
TABLE 3 Continued

\begin{tabular}{|c|c|c|}
\hline & Case A (ejido) & Case B (comunidad) \\
\hline $\begin{array}{l}\text { Physical } \\
\text { potential } \\
\text { for } \text { REDD+ }\end{array}$ & $\begin{array}{l}\text { (1) The best opportunities for } \\
\text { increasing carbon stock lie in the } \\
\text { pine/oak (2) The ejidatarios think this } \\
\text { can be achieved by more forest } \\
\text { patrols for which they would require } \\
\text { financial support; (3) External } \\
\text { experts thinks opportunities exist in } \\
\text { the management strategy used in the } \\
\text { productive forest, using different } \\
\text { extraction techniques in different } \\
\text { cycles, to increase overall carbon } \\
\text { stocks. }\end{array}$ & $\begin{array}{l}\text { (1) Forest is relatively well conserved } \\
\text { so few activities would be considered } \\
\text { additional in REDD+ terms; (2) The } \\
\text { area affected by fire is re-growing } \\
\text { through natural regeneration already; } \\
\text { (3) Reforesting of the encroached } \\
\text { areas could be considered additional } \\
\text { even though it is already occurring to } \\
\text { some extent; (4) Could claim that } \\
\text { without REDD+ the community } \\
\text { would at some time start to harvest } \\
\text { timber, and therefore that avoiding } \\
\text { this should be compensated by } \\
\text { REDD+. }\end{array}$ \\
\hline
\end{tabular}

\begin{tabular}{|c|c|c|}
\hline $\begin{array}{l}\text { Apparent } \\
\text { social } \\
\text { capital, } \\
\text { capacity for } \\
\text { social } \\
\text { organiza- } \\
\text { tion and } \\
\text { forest } \\
\text { governance }\end{array}$ & $\begin{array}{l}\text { (1) Strong leadership in forest } \\
\text { matters; (2) Active forest patrol } \\
\text { group which involves a small number } \\
\text { of ejidatarios only; (3) Ordinary } \\
\text { members of the ejido not aware/not } \\
\text { informed of PES programme; } \\
\text { (4) Financial benefits of the timber } \\
\text { sales are very small; (5) Leaders } \\
\text { claim to invest more than } 1 \text { million } \\
\text { pesos per year in forest patrols, and }\end{array}$ & $\begin{array}{l}\text { (1) Strong sense of community; } \\
\text { (2) High participation in forest } \\
\text { patrols (all male adult members); } \\
\text { (3) Many spoke against the idea of } \\
\text { timber extraction, claiming that the } \\
\text { benefits of the forest were in terms of } \\
\text { water and oxygen, not money; (4) } \\
\text { The community is not parcelised and } \\
\text { the boundaries marked on the map } \\
\text { are apparently correct. }\end{array}$ \\
\hline
\end{tabular}

Case C (comunidad and ejido)

(1) Reversing the degradation by halting illegal extraction; (2) Introducing a sustainable extraction plan (100 ha per year was suggested); (3) Strong enforcement would be required for successful implementation of these two strategies; (4) Reforestation along margins of agricultural land to discourage encroachment.

(1) This community has had internal conflicts for a very long time; (2) The imposition of rules relating to uses of forest in the buffer and core zones of the Reserve aggravated the conflicts; (3) The formation of the ejido escalated conflicts; (4) There is lack of enforcement of forest protection rules. say that agriculture is subsiding forest management in this ejido; (6) The ejido is not parcelised and has refused RAN registration on the basis that the boundaries are not correct.

\section{Attitudes \\ (1) There is not much understanding} towards REDD+ about what REDD+ would imply and what the benefits would be; (2) A study is being prepared by the local Forest Technician for a carbon project under a state programme (Secretaria de Urbansimo y Media Ambiente).
(1) A consultant earlier tried to engage the community in a carbon project in 2007 but this never materialized (the carbon programme, CABSA, which was part of CONAFOR's PES, was closed down shortly after that date); this has left people suspicious of REDD+; (2) Views were aired suggesting that researchers are paid to set up projects but the community hardly benefits;

(3) Others suggested that it would be worth finding out about the potential for REDD+ to see whether it is worthwhile to apply. (4) The main option proposed for promoting carbon stocks was payment for forest patrols.
(1) Most of the people at the meeting knew little about REDD+ but were in favour of conservation; however this was a biased group in the sense that the illegal fellers were not present; (2) Forest patrols were proposed as the solution, although the group was split as to whether this should be paid, or be a community obligation; (3) Arming the forest patrols to combat the armed illegal loggers was also proposed. 
TABLE 4 Characteristics of case study communities in the Ayuquila River Basin

\begin{tabular}{ll}
\hline & Case D (ejido) \\
\hline State of the & Hilly, quite heavily degraded TDF; \\
forests & was earlier completely deforested \\
& rangeland but forest re-grew after \\
& territory came under ejido control \\
& 40 years ago. Common use forest \\
& areas are already parceled infor- \\
& mally with fences, in strips from top \\
& of hill. Small diameters of the trees \\
& mean that they are not suitable for \\
& timber harvesting. 68\% of the ejido \\
& falls within de Sierra de Manantlán \\
& Biosphere Reserve; and 35\% was \\
& under PES from 2007 to 2011, this \\
& area overlapping the Reserve area \\
& (core and buffer zones), i.e. in the \\
& most hilly and inaccessible part of \\
& the ejido. Core area significantly \\
& less degraded than other areas.
\end{tabular}

Case E (ejido)

Oak-pine forests plus tropical dry forests in lower area with some small pure oak formations at midaltitude. Oak and pine forest was more extensive earlier but was slowly cleared for sale of construction wood. Until 20 years ago charcoal was also produced (this land now under shifting cultivation). Erosion is occurring in parts of the pine and oak forests. However many parts of forests are reasonably well conserved with wildlife. Small patches cleared for induced pasture.

\section{Case F (ejido)}

$75 \%$ of the territory is covered by TDF at different successional stages, mostly recovering from shifting cultivation which was halted over large areas in 2000; very small patches of oak and cloud forests at higher altitudes. Cattle, fire and selective logging also had a negative effect earlier, but since 2000, all these activities have been regulated and restricted to certain areas, mainly flat terrain. Vegetation along the rivers is recovering although little gallery forest remains. $70 \%$ of the ejido is within the Sierra de Manantlán Biosphere Reserve (core and buffer zones) and $81 \%$ of the ejido was under PES from 2007-2011. The ejido is currently re-applying for this programme. It also receives funds for conservation from the Cuencas Costeras programme.

\section{Uses of the} forest

\author{
In the parcelised areas: (1) Shifting \\ cultivation on the lower more \\ accessible slopes; (2) Cattle \\ grazing; majority of cattle belong to \\ people outside the ejido; (3) \\ Firewood and poles for domestic \\ purposes; (4) Hunting for own \\ supplies; (5) Collection of NTFPs \\ for food, medicine, and housing \\ construction materials. \\ In core zone of Reserve: no entry at \\ all is allowed in this area which is \\ kept for scientific purposes. \\ In PES area outside core zone cattle \\ is excluded but deadwood and \\ NTFPs may be collected.
}

\section{Forest man-} agement and conservation activities undertaken

\section{(1) Zoning, with areas of restricted} use due to Biosphere Reserve; (2) Ad hoc fire brigades; (3) Reforestation activities including seedling nursery; (4) Soil conservation activities; (5) Improved hillside agriculture using hedges, fruit and fodder trees.
(1) No shifting cultivation within the forests; all agricultural activities are allocated to a big common agricultural zone; (2) Forests used for grazing, except in areas that have been recently reforested; (3) Fuelwood and fence poles for domestic use; (4) Some hunting within the forests, but is not clear if this is done by local people or outsiders.
(1) Livestock officially restricted to areas outside the Reserve, but this is not strongly enforced. (2) Fuelwood; shortages have been reported. (3) Shifting cultivation in (unofficially divided) parcels of TDF, outside the Reserve area; restriction on use of land within the Reserve has probably have resulted in shorter fallow periods in this area; (4) Collection of NTFPs; (5) Poles for fencing.
(1) Reforestation; since 2009, 30,000 trees have been planted by the community.
(1) Zoning, with areas of restricted use due to Biosphere Reserve; (2) Fire brigades; (3) Actions to recover vegetation along the river margins;

(4) Ecotourism activities have proposed but not yet implemented. 
TABLE 4 Continued

\begin{tabular}{|c|c|c|c|}
\hline & Case D (ejido) & Case E (ejido) & Case F (ejido) \\
\hline $\begin{array}{l}\text { Physical } \\
\text { potential for } \\
\text { REDD+ }\end{array}$ & $\begin{array}{l}\text { (1) PES activity appears successful, } \\
\text { but area under PES is inaccessible } \\
\text { and therefore less under threat from } \\
\text { deforestation; (2) Forest degradation } \\
\text { from cattle grazing is more likely in } \\
\text { these upper areas; (3) Sustainable } \\
\text { timber management not an option as } \\
\text { tree diameters too small; (4) } \\
\text { REDD+ potential lies in promoting } \\
\text { natural regeneration of degraded } \\
\text { areas. }\end{array}$ & $\begin{array}{l}\text { (1) Relatively high level of conser- } \\
\text { vation means not much scope for } \\
\text { improvement; (2) Enhancement of } \\
\text { carbon stocks in abandoned fallows } \\
\text { of TDF is possible, although growth } \\
\text { rates are not very high; (3) Regula- } \\
\text { tion of access of cattle in oak/pine } \\
\text { forest could reduce degradation, } \\
\text { although magnitude of impact not } \\
\text { clear; (4) More reforestation } \\
\text { activities could be undertaken. }\end{array}$ & $\begin{array}{l}\text { (1) A large part of its forests are } \\
\text { already under conservation orders } \\
\text { so there may not be much more } \\
\text { scope for REDD+; (2) There is a } \\
\text { potential threat of limestone } \\
\text { extraction (the area is part of a } \\
\text { concession), avoidance of this could } \\
\text { be considered for REDD+; (3) May } \\
\text { be difficult to enhance forest stocks } \\
\text { in the shifting cultivation areas as } \\
\text { the area zoned for this is already } \\
\text { small and cycles have been } \\
\text { shortened to accommodate farmers } \\
\text { needs; (4) Reforestation of river } \\
\text { margins with native species others } \\
\text { could be undertaken. }\end{array}$ \\
\hline
\end{tabular}

Apparent
social capital,
capacity for
social organi-
zation and
forest gover-
nance

(1) Strong leadership in forest activities by a small group of persons; (2) Water supply is a major community concern motivating people to better forest management; (3) No conflicts evident as regards the PES area or use of the PES funds; (4) Increasing pressure from cattle owners and those who rent to them to relax the rules (which are often ignored); (5) The decisions of the ejido are influenced by the leaders of the biosphere reserve, who have helped them get e.g. PES funds; (6) Monthly Assemblies are held.
(1) Small and well organized community with strong leadership and common religious beliefs; (2) Land is zoned and the division of uses is respected by all, no major conflicts have occurred; (3) Forest land is held in common, not parcelised; (4) Cultivation land is in one block, farmed individually but not privatized; living fences distinguish where each ejidatario's crop starts and finishes, shifting cultivation cycles are organized/ coordinated; they move all together to the next piece of land and leave the earlier one to rest; (5) High community commitment to cooperate; (6) Monthly Assemblies are held.

Attitudes
towards
REDD+

(1) Understand the concept of carbon credits, are somewhat afraid of this idea which seems abstract to them. Not sure how they would be measured, and unsure what happens if they do not achieve the expected increases in carbon stocks; (2) Prefer to obtain funds directly from foreign buyers rather than via a government programme (but think there will be a language problem here); (3) Ejido authorities are worried about how carbon benefits in cash would be divided internally (4) They recognize that reducing degradation would impact their cattle keeping activities and are not sure how to deal with this.

\section{(1) The community wants to} continue with the traditions of their grandparents as regards shifting cultivation but believe this is causing degradation. (2) Consider that forests provide them with important environmental services, as evidenced by the amount of water in the river and wildlife since forest was left to regenerate naturally; (3) They have heard about REDD+ and believe that there are $\$ 5 \mathrm{~m}$ in Mexico for it; (4) They are very concerned about the tradeoffs between agricultural production (particularly cattle rearing) and REDD+; (5) They want to know the specific rules governing REDD+ before deciding whether to participate.
(1) Small ejido, classified as 'highly marginalised' with high level of adult illiteracy; (2) No full consensus concerning conservation, some members voiced doubts about participating; (3) Nevertheless, two conservation initiatives are ongoing, indicating some degree of leadership and organization; (4) Infrequent Assembly meetings.

(1) They are aware of climate change and see some effects such as erosion. (2) Some members of community expressed interest in participating in REDD+ but are concerned about duration, payment and what is expected of them, particularly as regards what will happen to their livestock; (3) Not all members are in favour of conservation approaches; (4) They prefer to wait to see how other ejidos fare with REDD+ before committing themselves; (5) They proposed REDD+ payment in the form of food (maize) instead of money. 
TABLE 5 Characteristics of case study community in the Coastal Watersheds Region of Jalisco

\begin{tabular}{ll}
\hline Case G (ejido) \\
\hline State of the forest & $\begin{array}{l}\text { Large continuum of forest (TDF, oak, pine-oak, cloud forest) with a few cultivated areas (parcels) embed- } \\
\text { ded. The condition of most forest is good, although in the pine-oak forest there have been legal extractions } \\
\text { in the last } 35 \text { years with erosion along timber roads, and some extraction in oak forest for local use (mainly } \\
\text { for fencing). Large areas of cloud forest are far from the population centers and are well preserved, they } \\
\text { have been covered by a PES agreement since 2012. The TDF near rivers or streams is well preserved. Fires } \\
\text { have affected pine-oak and oak forests. The expansion of grasslands has degraded forests near the cultivated } \\
\text { patches. The forest area is informally divided into parcels and fenced for cattle grazing, but not all } \\
\text { ejidatarios have such a parcel (there were trade-offs with cultivation land). }\end{array}$ \\
\hline
\end{tabular}

Uses of the forest (1) No shifting cultivation; (2) Cattle grazing occurs on almost all forests, except very steep and distant areas; (3) Legal logging in pine-oak forest 2002-2012 by forest company, but permission not renewed yet; (4) Extraction of wood for personal and domestic use.

$\begin{array}{ll}\begin{array}{l}\text { Forest management } \\ \text { and conservation }\end{array} & \begin{array}{l}\text { activities; (2) Through the sales of timber and a trust fund the ejido acquired sawmill machinery twenty } \\ \text { activities under- } \\ \text { taken }\end{array} \\ \begin{array}{l}\text { years ago, but this was never used, perhaps due to conflicts with the company; (3) Reforestation, fire } \\ \text { watching, fire fighting and forest patrols as stipulated in management plan and financed by timber company, } \\ \text { organized by community leaders. }\end{array}\end{array}$

Physical potential (1) Enhancement of carbon stock in pine-oak and oak forests, average tree diameters have been reduced due for REDD+ $\quad$ to extraction of larger trunks; (2) Protection and propagation in particular of an endangered (IUCN Red List) pine species; (3) More monitoring and firefighting; (4) Reducing cattle pressure in forested areas to increase natural regeneration and decrease erosion.

\begin{tabular}{ll}
$\begin{array}{l}\text { Apparent social } \\
\text { capital, capacity for } \\
\text { social organization } \\
\text { and forest gover- } \\
\text { nance }\end{array}$ & $\begin{array}{l}\text { (1) Conflicts between the members of the ejido because forested land was informally parcelised for grazing } \\
\text { divided between all ejidatarios but those forest parcels are claiming a larger share of the profits since they } \\
\text { take care of this area and also because after the timber extraction their areas are degraded (their fences are } \\
\text { demolished and they lose cattle in accidents on timber roads). Some fire incidents have been related to these } \\
\text { conflicts; (2) Strong leadership on forest management recently but low participation by the majority, who } \\
\text { perceived low benefits from forests; (3) Most do not know much about the PES but it is accepted because } \\
\text { the area concerned has no productive uses; (4) People recognize the importance of riparian forests to } \\
\text { maintain water flow; (5) Compensation for conservation of the forests (PES) is well accepted as benefits } \\
\text { from the timber extraction are low (and conserved area has no other use). }\end{array}$ \\
\hline
\end{tabular}
Attitudes toward
(1) Ejidatarios do not know about REDD+ and carbon capture although they understand and accept PES.

REDD+

\section{DISCUSSION AND CONCLUSIONS}

Despite the fact that the villages are all in REDD+ Early Action Areas where there is said to be a threat of deforestation, in practice their levels of deforestation are very low. However, they all have forests which are degraded at least in parts, so the opportunities for REDD+ lie in reversing any on-going degradation and creating forest enhancement. Whether such interventions will be considered additional however depends on the baseline that is used, since some, though not all, have been engaging for several years in forest management activities which are already reducing degradation and resulting in forest enhancement, i.e. bringing about landscape transitions towards higher carbon stocks. Failure to achieve additionality does not imply that communities will not receive REDD+ benefits, since CONAFOR has already made clear that its payments to communities will be provided not on the basis of performance, but as inputs for planned forest management activities. However additionality is significant in the bigger picture since in order to generate credits for international exchange, CONAFOR will have to demonstrate that the results would not have occurred had REDD+ not been implemented. A possible conclusion could be that CONAFOR and TNC are focusing on the wrong zones for their Early Action Areas, selecting those which had been identified at least a decade ago as under threat, but where there have already been many relatively successful interventions. More credits might be earned under REDD+ by focusing on areas which have received very few forest subsidies up to now, particularly in the large areas of TDF which are heavily degraded.

We observed that the potential for REDD+ and successful transformation of forest landscapes at local level will also depend on the size of the forest resources and in particular the population density vis-a-vis forest area. The villages in the MBBR area have vastly less forest per head than those in Ayuquila and Chamela, which means not only that the use pressure per hectare is larger (and thus the opportunity costs 
higher), but also that the potential financial benefits of protecting it will be much lower per head. Payments will be made for inputs in forest management, which will inevitably be related for the area available for treatment. The forest area per head varies from $0.30-0.75$ ha in the MBBR area to 3-7 ha in Jalisco (i.e. by a factor of 10). This would be of considerable significance if communities decide to share out any financial benefits (such as paid labour days) between their inhabitants. The potential returns may be so small in the MBBR communities as to fail to work as an incentive. The question of varying size of resource base per community does not appear to have entered into discussions on REDD+ in Mexico or indeed in other countries that are pursuing community forestry for REDD+, but is clearly a factor that needs to be taken into consideration.

In terms of kinds of activities envisaged by communities as contributions to REDD+, most saw PES as the model, though recognizing also that e.g. sustainable extraction of timber might be an option in the temperate forest zones (thus not in TDF areas of Jalisco). The perceived opportunity costs and trade-offs of such REDD+ activities against existing uses of forest vary by zone. In the Ayuquila area the cost of possible prohibition of forest grazing was identified by communities as a major concern, though shifting cultivation was not mentioned in this regard. In MBBR these practices do not occur in the forest, and timber removals have already been largely curtailed in two of the three communities. In the MBBR villages there was in fact more concern about implementation costs, particularly for payment of forest brigades to conduct patrols, than about opportunity costs.

The social-organisational capacity of the communities varied greatly. Where there are long running internal conflicts or conflicts with outsiders it appears likely that the potential of the communities concerned to engage in REDD+ will be reduced. Such conflicts are the result of very specific histories of individual communities in their local geographical context and are not related to any particular zone. This is not a surprising outcome, but it is not one that can easily be resolved.

Locally, support for REDD+ may also relate to the way in which any benefits are distributed within the community. Communities could decide that only rights-holders are eligible for REDD+ benefits such as paid labour days. The potential returns to families with rights would then vary by a factor of 20 across the seven cases, depending on the endowment of the forest in different localities (Table 2). But we see also that a large number of rural families, particularly in ejidos, do not have rights: up to $53 \%$ of the households, in one of our cases; they might receive nothing at all. The situation in the comunidades is less extreme owing to the fact that in these settlements most males are incorporated as members when they attain the age of 18 . The question of who would have rights to benefits - only the ejidatarios/comuneros, or all families was, with one exception, not openly aired in the community discussions. However the fact that large numbers of families are without rights could make REDD+ extremely socially divisive, since the non-rights holders (like rights-holders) would presumably be forced to reduce their subsistence use of forest products, but unlike rights-holders they would receive no compensation. There is a clear risk here that the underprivileged families might sabotage the REDD+ efforts. That said, there are indications that not all the rewards in the national REDD+ programme rewards will be distributed in monetary form (SEMARNAT 2014). Were they to be used in part for community infrastructure, for example, then the benefits might be much more evenly distributed.

Whether REDD+ will be attractive to communities will in reality mainly depend on the amounts paid. If the fund available for payments is limited to what can be earned through national sales of carbon credits at market prices, this would result in very low payback per hectare, probably well below the rates that are currently paid for PES, and CONAFOR has therefore indicated that it will supplement the fund from regular internal financial resources. The fact is, however, that communities are at present totally unaware of what rates are likely to be involved. Local views on REDD+ are now therefore mainly of the 'wait and see' variety and are likely to remain so until much more clarity is provided.

Our analysis is preliminary, and focused on a limited number of cases in Jalisco and Michoacan. The situation in other parts of the country could be different, and would need to be investigated before overall conclusions are drawn. Nevertheless the study has raised a number of issues which need to be aired and discussed as national REDD+ policy develops in Mexico. These issues may also be of relevance in other countries.

\section{REFERENCES}

ALIX-GARCIA, J., DE JANVRY, A., SADOULET, E., TORRES, J.M., VARELA, J.B. and RAMOS, M.Z. 2005. An assessment of Mexico's payment for environmental services program. Unpublished paper prepared for FAO by UC Berkeley and the Centre for Research and Teaching of Economics, Mexico.

ALIX-GARCIA, J.M., SHAPIRO, E.N. and SIMS, K.R.E. 2012. Forest conservation and slippage: evidence from Mexico's national Payment for Ecosystem Services program. Land Economics 88(4): 613-638.

ANGELSEN, A., BROCKHAUS, M., SUNDERLIN, W.D. and VERCHOT, L.V. 2012. Analysing REDD+: Challenges and choices. Bogor, Indonesia, Center for International Forestry Research (CIFOR).

ANGELSEN, A. and KAIMOWITZ, D. 1999. Rethinking the causes of deforestation: Lessons from economic models. World Bank Research Observer 14(1): 73-98.

ASSIES, W. 2008. Land tenure and tenure regimes in Mexico. an overview. Journal of Agrarian Change 8(1): 33-63.

BALDERAS TORRES, A. and SKUTSCH, M. 2012. Splitting the difference: a proposal for benefit sharing in Reduced Emissions from Deforestation and forest Degradation (REDD+). Forests 3(1): 137-154.

BALOONI, K. and LUND, J.F. 2013. Forest rights: the hard currency of REDD+. Conservation Letters 7(3): 278-284. 
BALVANERA, P. 2012. Los servicios ecosistémicos que ofrecen los bosques tropicales. Revista Ecosistemas 21(1-2): 136-147.

BRAY,D.B., MERINO-PÉREZ, L., NEGREROS-CASTILLO, P., SEGURA-WARNHOLTZ, G., TORRES-ROJO, J.M. and VESTER, H.F.M. 2003. Mexico's community managed forests as a global model for sustainable landscapes. Conservation Biology 17(3): 672-677.

CÁMERA DE DIPUTADOS. Ley Agraria, 1992. Cámara de Diputados del H. Congreso de la Unión. Diario Oficial de la Federación 26 de febrero 1992.

CARILLO, J.J.L. MOTA-VILLANUEVA (eds). Guía Legal para Dueños de Bosques en México. WWF-México, 2006. 204 p. http://www.cemda.org.mx/wp-content/uploads/ 2011/12/gu\%C3\%ADa-forestal-final.pdf http://www. diputados.gob.mx/LeyesBiblio/pdf/13.pdf.

COUTURIER, S., NÚÑ̃E, J.M. and KOLB, M. 2012. Measuring tropical deforestation and error margins: a method for REDD monitoring in South-Eastern Mexico. Tropical Forests. P. Sudarshana, InTech: 269-296.

CHHATRE, A. and AGRAWAL, A. 2009. Trade-offs and synergies between carbon storage and livelihood benefits from forest commons. Proceedings of the National Academy of Sciences 106(42): 17667-17670.

DANIELSEN, F., SKUTSCH, M., BURGESS, N.D., JENSEN, P.M., ANDRIANANDRASANA, H., KARKY, B., LEWIS, R., LOVETT, J.C., MASSAO, J., NGAGA, Y., PHARTIYAL, P., POULSEN, M.K., SINGH, S.P., SOLIS, S., SØRENSEN, M., TEWARI, A., YOUNG, R. and ZAHABU, E. 2011. At the heart of REDD+: a role for local people in monitoring forests? Conservation Letters 4(2): 158-167.

DE AZCÁRATE, J.G., RAMÍREZ, M.I. and PINTO, M. 2003. Las comunidades vegetales de la Sierra de Angangueo (estados de Michoacán y México, México): clasificación, composición y distribución. Lazaroa 24: 87-111.

DEFRIES, R.S., RUDEL, T., URIARTE, M. and HANSEN, M. 2010. Deforestation driven by urban population growth and agricultural trade in the twenty-first century. Nature Geosci 3(3): 178-181.

DI GREGORIO, M., BROCKHAUS, M., CRONIN, T., MUHARROM, E., SANTOSO, L., MARDIAH, S. and BÜDENBENDER, M. 2013. Equity and REDD+ in the media: a comparative analysis of policy discourses. Ecology and Society 18(2): 580-594.

FAO. 2010. Global Forest Resources Assessment 2010 Main Report. F. a. A. Organization. Rome, FAO: 378.

GAVEAU, D.L.A., WICH, S., EPTING, J., JUHN, D., KANNINEN, M. and LEADER-WILLIAMS, N. 2009. The future of forests and orangutans (Pongo abelii) in Sumatra: predicting impacts of oil palm plantations, road construction, and mechanisms for reducing carbon emissions from deforestation. Environmental Research Letters 4(3): 034013.

GEIST, H.J. and LAMBIN, E. 2001. What drives tropical deforestation? A meta-analysis of proximate and underlying causes of deforestation based on subnational case study evidence. LUCC Report Series No. 4, Louvain-laNeuve (Belgium): LUCC International Project Office.

GEIST, H.J. and LAMBIN, E.F. 2002. Proximate causes and underlying driving forces of tropical deforestation. BioScience 52(2): 143-150.

HONEY-ROSÉS, J. 2009. Disentangling the proximate factors of deforestation: The case of the Monarch butterfly Biosphere Reserve in Mexico. Land Degradation and Development 20(1): 22-32.

HONEY-ROSÉS, J., BAYLIS, K. and RAMÍREZ, M.I. 2011. A spatially explicit estimate of avoided forest loss. Conservation Biology 25(5): 1032-1043.

INEGI 2010. Instituto Nacional de Estadistica y Geografía: Census y Conteos de Población y Viviendas. http://www. inegi.org.mx/sistemas/consulta_resultados/iter2010. aspx?c=27329\&s=est.

JARDEL, E.J. 1998. Efectos ecológicos y sociales de la explotación maderera de los bosques de la Sierra de Manantlán. El Occidente de México: arqueología, historia y medio ambiente. Perspectivas regionales. R. Ávila, J.P. Emphoux, L.G. Gastélumet al. Guadalajara, Mexico, Universidad de Guadalajara: 231-251.

MAASS, J.M., BALVANERA, P., CASTILlO, A., DAILY, G.C., MOONEY, H.A., EHRLICH, P., QUESADA, M., MIRANDA, A., JARAMILLO, V.J. and GARCÍA-OLIVA, F. 2005. Ecosystem services of tropical dry forests: insights from long-term ecological and social research on the Pacific Coast of Mexico. Ecology and Society 10(1): 17.

MCDERMOTT, C.L., COAD, L., HELFGOTT, A. and SCHROEDER, H. 2012. Operationalizing social safeguards in REDD+: actors, interests and ideas. Environmental Science and Policy 21(0): 63-72.

MISSRIE, M. and NELSON, K. 2005. Direct payments for conservation: lessons from the Monarch Butterfly Conservation Fund. Economics 88(3): 339-353.

MONROY SAIS, A.S. 2013. Histoira, uso y manejo de los bosques en un ejido de la región Chamela-Cuixmala, Jalisco. Master's thesis in Biological Sciences, Centro de Investigaciones en Ecosistemas, Universidad Nacional Autonoma de Mexico, Morelia.

MUÑOZ-PIÑA, C., GUEVARA, A., TORRES, J.M. and BRAÑA, J. 2008. Paying for the hydrological services of Mexico's forests: Analysis, negotiations and results. Ecological Economics 65(4): 725-736.

NAVARRETE, J.-L., ISABEL RAMÍREZ, M. and PÉREZSALICRUP, D.R. 2011. Logging within protected areas: spatial evaluation of the Monarch Butterfly Biosphere Reserve, Mexico. Forest Ecology and Management 262(4): 646-654.

PACHECO, P. 2006. Agricultural expansion and deforestation in lowland Bolivia: the import substitution versus the structural adjustment model. Land Use Policy 23(3): 205-225.

PHELPS, J., WEBB, E.L. and AGRAWAL, A. 2010. Does REDD+ threaten to recentralize forest governance? Science 328(5976): 312-313. 
RAMÍREZ, M.I., SÁENZ-ROMERO, C., REHFELDT, G.E. and SALAS-CANELA, L. 2014. Threats to the availability of overwintering habitat in the Monarch Butterfly Biosphere Reserve: land use and climate change. Monarchs in a changing world: biology and conservation of an iconic insect. K.S. Oberhauser, K.R. Nail and S.M. Altizer. Ithaca, NY, Cornell University Press.

ROBLES, H.M. 1996 Tipología de los sujetos agrarios Procede. EstudiosAgraria 4.

SALINAS-MELGOZA, M.A., SKUTSCH, M. and LOVETT, J.C. (2014) Shifting cultivation in the context of REDD+; a case study of Mexican tropical dry forest. Submitted to Land Use Policy (currently under review).

SCHROEDER, H. 2010. Agency in international climate negotiations: the case of indigenous peoples and avoided deforestation. International Environmental Agreements: Politics, Law and Economics 10(4): 317-332.

SEMARNAT, 2010. Vision de México sobre REDD+. Hacia un estrategia nacional. http://www.conafor.gob.mx:8080/ documentos/docs/7/1393Visi\%C3\%B3n\%20de\%20M\% C3\%A9xico\%20sobre\%20REDD_.pdf.

SEMARNAT, 2011. Forest Investment Program: Investment Plan Mexico. http://www.conafor.gob.mx:8080/documentos/docs/35/2603Plan\%20de\%20Inversi\%C3\%B3n\% 20Forestal\%20de\%20M\%C3\%A9xico.pdf.

SEMARNAT, 2013. Estrategia Nacional para REDD+ (ENAREDD+) (draft).
SEMARNAT, 2014. Emision reduction program idea note (ER-PIN) submitted to the Forest Carbon Partnership of the World Bank (draft).

SKUTSCH, M. and MCCALL, M. 2012. The role of community forest management in REDD+. Unasylva 239(63): 51-56.

SKUTSCH, M., SIMON, C., VELAZQUEZ, A. and FERNÁNDEZ, J.C. 2013. Rights to carbon and payments for services rendered under REDD+: Options for the case of Mexico. Global Environmental Change 23(4): 813-825.

SMITH, J. and SCHERR, S.J. 2003. Capturing the value of forest carbon for local livelihoods. World Development 31(12): 2143-2160.

TREJO, I. and DIRZO, R. 2000. Deforestation of seasonally dry tropical forest: a national and local analysis in Mexico. Biological Conservation 94(2): 133-142.

VELÁZQUEZ, A., MAS, J., GALLEGOS, J.R.D., MAYORGA-SAUCEDO, R., ALCÁNTARA, P., CASTRO, R., FERNÁNDEZ, T., BOCCO, G., EZCURRA, Y.E. and PALACIO, J. 2002. Patrones y tasas de cambio de uso del suelo en México. Gaceta ecológica (62): 21-37.

VIDAL, O., LÓPEZ-GARCÍA, J. and RENDÓN-SALINAS, E. 2014. Trends in deforestation and forest degradation after a decade of monitoring in the Monarch Butterfly Biosphere Reserve in Mexico. Conservation Biology 28(1): 177-186. 